\title{
宮崎海岸の土砂移動の実態
}

\section{The Analysis of Sediment Transport of Miyazaki Coast by the Sand Tracer Experiment}

\author{
杉山光徳 $^{1} \cdot{\text { 門田 } \text { 仁 }^{2} \cdot \text { 堀口敬洋 }}^{3} \cdot$ 八木裕子 ${ }^{4} \cdot$ 永田千広 $^{5} \cdot$ 高木利光 $^{6}$ \\ Mitsunori SUGIYAMA, Hitoshi KADOTA, Takahiro HORIGUCHI, Hiroko YAGI \\ Chihiro NAGATA and Toshimitsu TAKAGI
}

\begin{abstract}
The purpose of this study is to analyze the sediment transport of Miyazaki Coast, especially the dominant longshore direction of sand transport, from the results of recent 3 years sand tracer experiment and of the analysis of currents observed by camera systems during the experiment. The dominant direction obtained by accumulation of longshore sediment transport rate estimated by equation of Kraus et al.(1982), which is based on the breaking wave height and nearshore currents, agrees with the direction of motion of the tracer. In addition, it becomes clear that there is a high correlation between the distance of tracer movement and the longshore sediment transport rate. It is also obvious that sediment transport to south is predominant in the experiment period.
\end{abstract}

\section{1. はじめに}

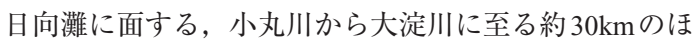
ぼ直線状の砂礫海岸には，小丸川，一ツ瀬川，大淀川が 流入するとともに，一ツ瀬川導流堤，宮崎港などの構造 物も存在する (図-1). 近年, この一連の海岸のうち, 一 ツ瀬川よりも南側に位置する海岸で侵食が顕在化してお り，2008年 4 月から一ツ瀬川〜大淀川間の港湾 · 漁港 · 河川区域を除く約 $6.9 \mathrm{~km}$ の海岸が宮崎海岸として新規直 轄化され, 漂砂制御施設に極力頼らない土砂管理を主体 とした海岸侵食対策に取り組んでいるところである.

養浜を含む土砂管理を主体として効果的・効率的に海 岸侵食対策を着実に進めるためには, 土砂移動（漂砂） の実態を解明する必要がある。宮崎海岸では, これまで に漂砂の動態解明のためのトレーサー調査を実施してい るものの，2006年 8 月 25 日〜 10 月 25 日と短期間の調査 （藤原ら，2007）であった。そこで, 本調査は2006年 1 月〜 2008 年 11 月の約 3 年間に渡るトレーサー調査および その期間の波浪・流況解析結果から, 通年の漂砂の実態, 特に沿岸漂砂の方向について検討したものである.

\section{2. 漂砂調査の実施概要}

\section{（1）トレーサー調査}

宮崎海岸では，2006年1月〜2007年9月までの間に投 入場所・時期が異なる計 6 種類のトレーサーを計 4 箇所

1

2

3 正会員

4 业会員 (工)

5 修 (工)

6 フェロー 博(工)
国土交通省九州地方整備局宮崎河川国道 事務所河川管理課長, 前海岸課長 国土交通省九州地方整備局宮崎河川国道 事務所海岸課海岸係長 株式会社アイ・エヌ・エー海岸部 株式会社アイ・エヌ・エー海岸部 株式会社アイ・エヌ・エー海岸部 株式会社アイ・エヌ・エー海岸部長
に投入している (図-1). 具体的には, 粒径 $0.2 \sim 2 \mathrm{~mm}$ の 着色砂を用いて，2006年1月19日に2箇所（赤色，淡い 青色), その 6 ケ月後の 2006 年 8 月 25 日に 1 月と同じ 2 箇 所に色の異なる着色砂（青色, 緑色）を投入しており, さらにその約 1 年後の 2007 年 7 月 13 日に 1 箇所 (黄色), その 2 ケ月後の 2007 年 9 月 11 日に 1 箇所（赤色蛍光砂） 投入している。トレーサーの投入量はいずれの地点も $2 \mathrm{~m}^{3}$ であり, 汀線付近に投入しているため, 投入直後か ら遡上する波が作用している。 なお，黄色トレーサーは， 2006 年 12 月〜 2007 年 3 月にかけて後浜部に盛土形状で約 2.6 万 $\mathrm{m}^{3}$ の養浜が実施された箇所の沿岸方向ほぼ中央部 の養浜法肩部に，2007年2月27日に埋設したものである が, それから約 4 ケ月後の T0704号来襲時に養浜材とと もに海域に流出が確認されたため投入時期を 2007 年 7 月 13 日としている。

トレーサー投入後の移動状況を把握するために，2006 年 10 月 25 日，2008年 1 月 $15 \sim 16$ 日，2008年 11 月 $17 〜 20$ 日に，一ツ瀬川河口近傍から宮崎港に至るバーム頂部 (通常の波の遡上端近傍) で底質採取を実施し, 採取し た試料に含まれているトレーサーを検出した。なお， 2006 年 10 月および2008年 11 月調査時には海中部の底質 も採取し，トレーサーを検出している.

\section{(2) 波浪観測}

トレーサー調査期間中の来襲波浪の観測は, 宮崎港防 波堤沖水深約 $15 \mathrm{~m}$ （図-1）において, 宮崎県により超音 波式波高計および電磁流速計を用いて実施されている. その観測データを解析し, トレーサー調査期間中の波浪 特性を把握した。

\section{（3）定点固定カメラによる流況観測}

宮崎海岸では2006年1月以降, 一ツ瀬川左岸 (A), 大 炊田海岸（B), 石崎浜海岸（C）および一ツ葉有料PA 


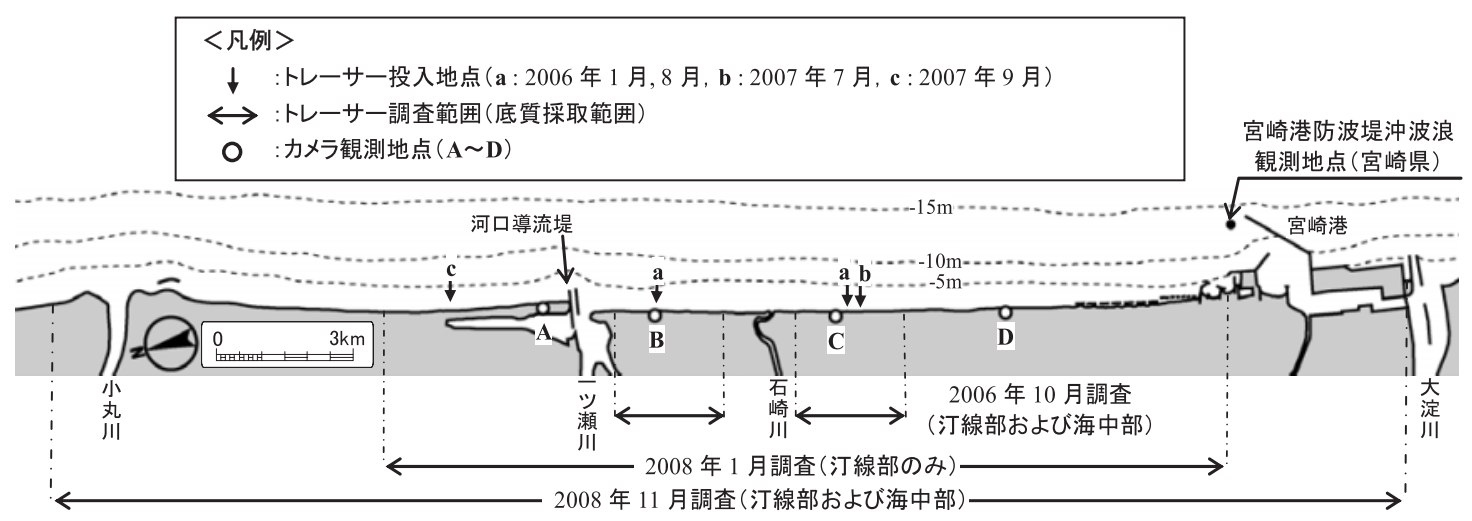

図-1 調查位置図

（D）の代表4地点で定点固定カメラ観測を実施している. 観測は，毎日 7〜 18 時の毎正時前後5 分間（10分/時間） に $0.5 \mathrm{~s}$ 間隔で実施し，1 回の観測で計 1200 枚のjpeg画像 $(640 \times 480$ ピクセル) を取得している。トレーサー調査 期間中の流況として，この取得画像を解析し砕波帯内の 沿岸流速を求めた。 なお, 解析方法は, 藤原ら（2007） と同様の方法とした。

\section{3. トレーサー調査の結果}

\section{(1) 2006 年 10 月調査}

2006 年 10 月のトレーサー調査結果によると，2006年 1 月および8月に大炊田海岸（図-2（a））よび石崎浜海 岸（図-2（b)）に投入したトレーサーは，いずれも投入 地点より南側において多く検出された。

\section{(2) 2008 年 1 月調查}

2008 年 1 月のトレーサー調査結果（図-3）によると， 石崎浜海岸の養浜地点に 2007 年 7 月に投入したトレーサ 一は, 投入地点近傍およびそれより北側で確認された. これに対し，トレーサー投入から 1 年以上経過している ものは，投入地点より南側において多く検出された。
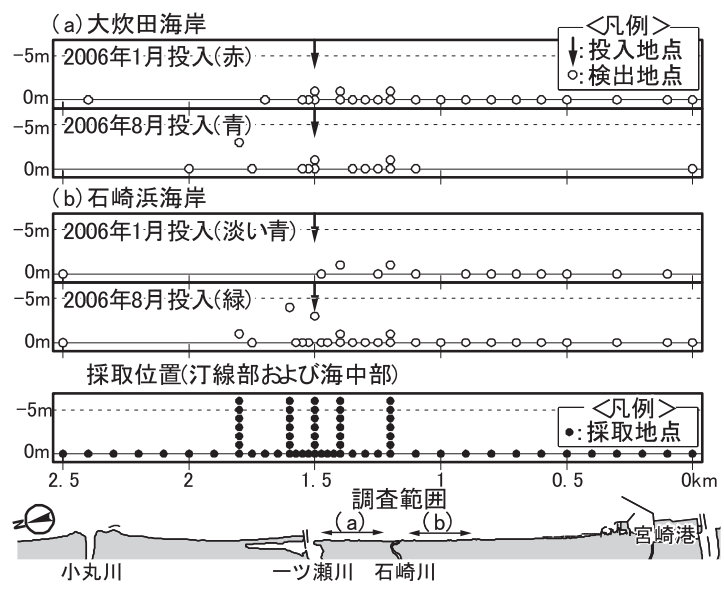

図-2２006年10月トレーサー調査結果

\section{(3) 2008 年 11 月調査}

2008 年 11 月のトレーサー調査結果（図-4）によると， 2006 年 1 月に 2 箇所に投入したトレーサーについては投 入位置から北に移動したものもあるが，南側に多く検出 されている。 それ以降4箇所に投入されたトレーサーは 投入箇所近傍以外の北側では検出されず，すべて南側で 検出された。

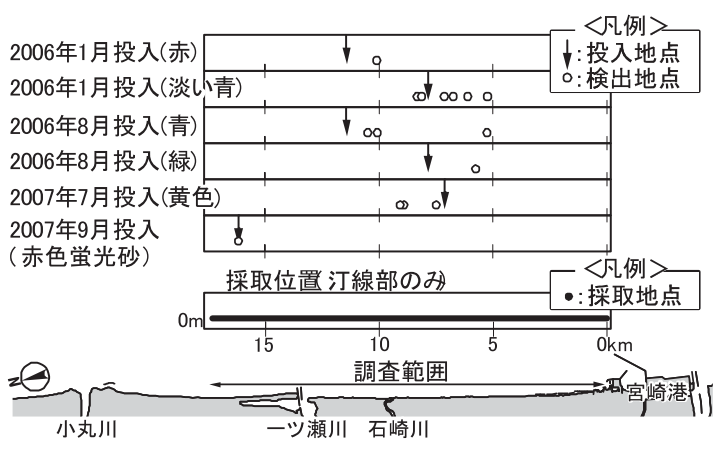

図-3 2008年1月トレーサー調査結果
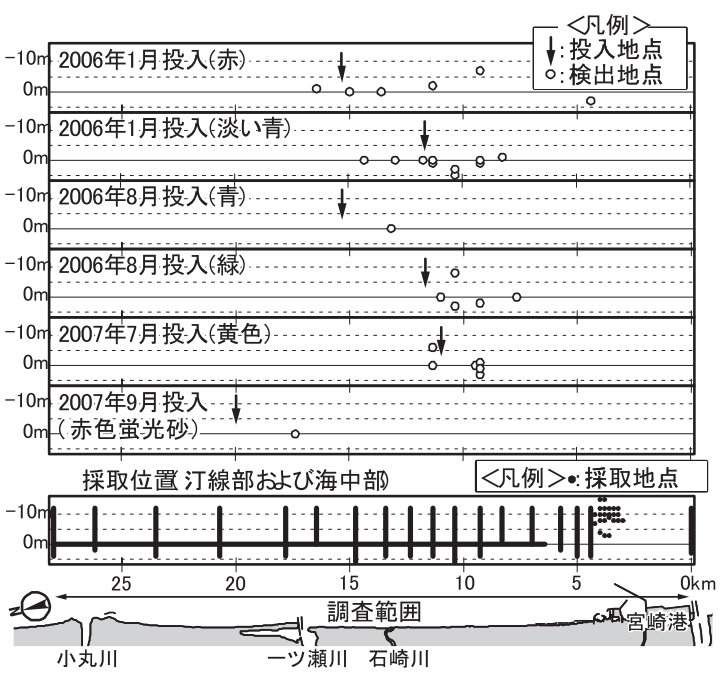

図-42008年11月トレーサー調査結果 


\section{4. 波浪・流況観測の結果}

\section{（1）波浪観測}

2006 年 1 月～2008年 12 月の宮崎港防波堤沖の波浪観測 データを用いた波向別の波浪エネルギーフラックス比の 算定結果を図-5に示す。この結果によると，期間中に観 測された波浪の波向は， $82^{\circ}$ をピークに $70 〜 96^{\circ}$ の範囲に 集中している．海岸線（海岸線に対する代表的な直角方

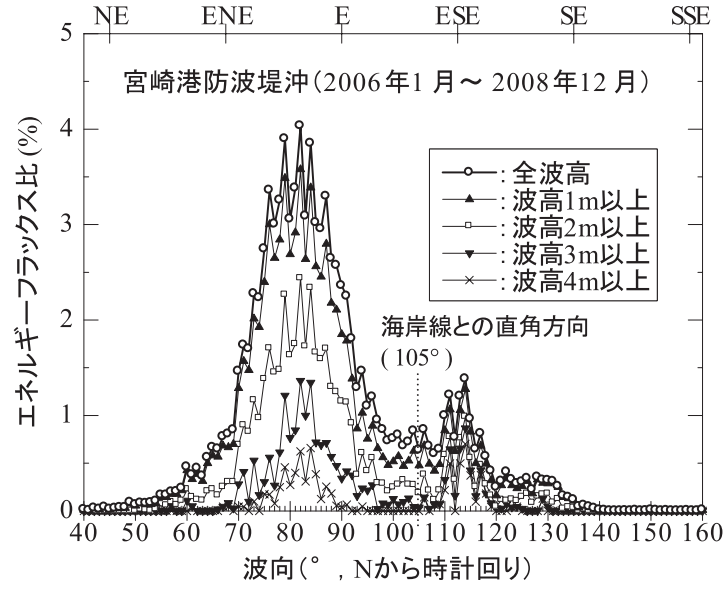

向：105）に対して左手（北寄り）からの入射となるた め，南向きの波浪エネルギーフラックスが卓越していた と推定される。

（2）定点固定カメラによる流況観測

2006 年 1 月〜 2008 年 12 月の 3 年間における日・月平均 沿岸流速の経時変化を図-6に示す。なお，図中上部には， 宮崎港防波堤沖で観測された日最大有義波，日平均波浪 エネルギーフラックスの沿岸方向成分およびトレーサー 調査の実施状況を併せて示している．この結果によると， $\mathrm{A} \sim \mathrm{D}$ の各観測地点での日平均沿岸流速は, いずれの地 点においても期間を通して概ね $\pm 1 \mathrm{~m} / \mathrm{s}$ （北向きが+）の 範囲であり，藤原ら（2007）の結果と同様であった。一 方, 月平均流速でみると，2006年7月，2007年5〜8月に は北向きの沿岸流が卓越している時期もあるが，観測期 間中は概ね南向きの流れが卓越している結果となった.

次に, トレーサー調査期間中, 唯一北向きの移動が確 認された黄色トレーサー（図-3）投入前後の 2007 年 7 月 12〜15日の外力状況を図-7に示す。この結果によると， この期間にはT0704による高波浪 (期間最大 $\mathrm{H}_{1 / 3}=6.45 \mathrm{~m}$, $\mathrm{T}_{1 / 3}=11.2 \mathrm{~s}$ ）が来襲しており, その時の波向は期間を通 して南寄りで，流れは北向きであったことがわかる.

図-5 宮崎港防波堤沖の波向別エネルギーフラックス比

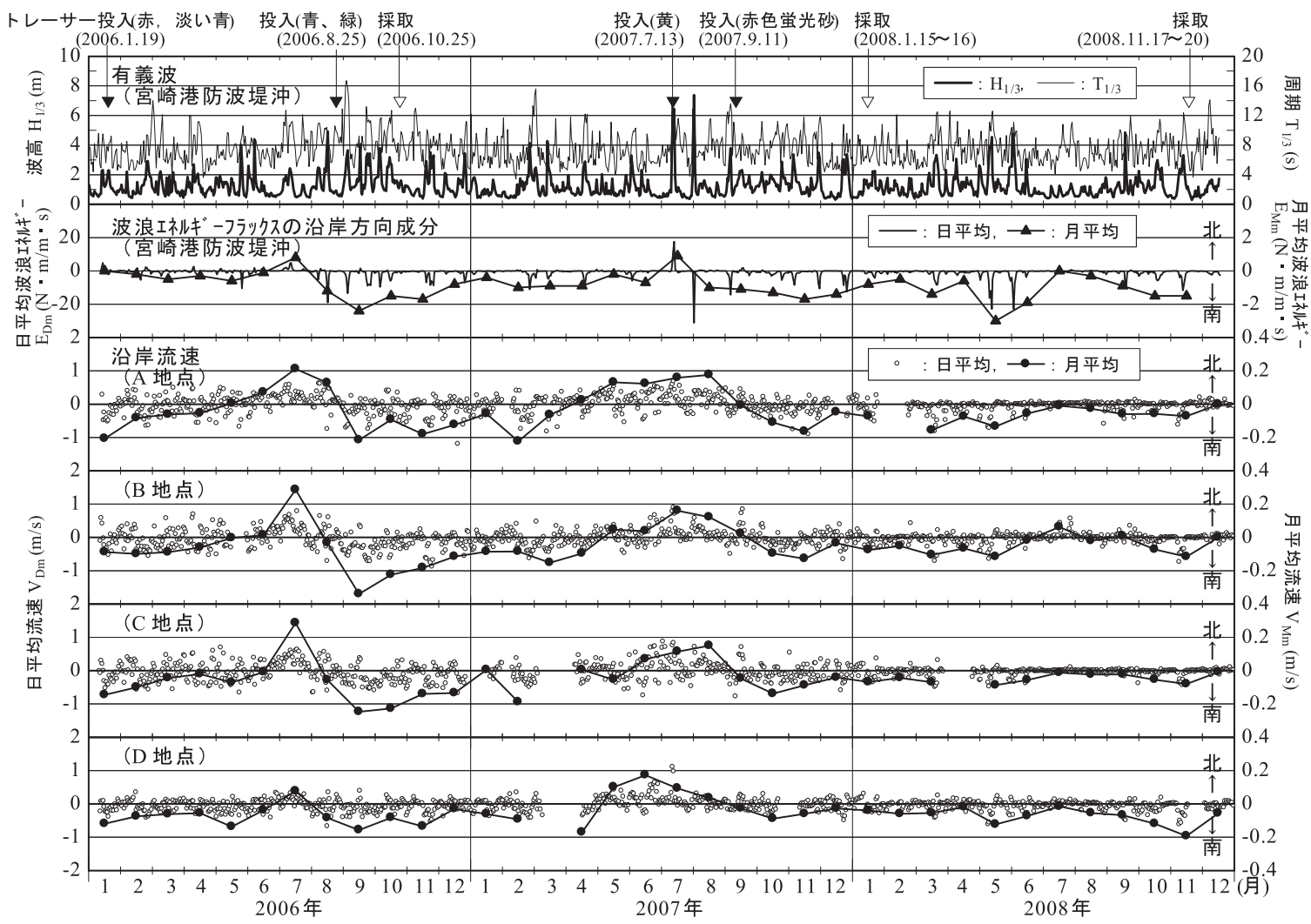

図-6 2006年1月～2008年12月の波浪・流況 


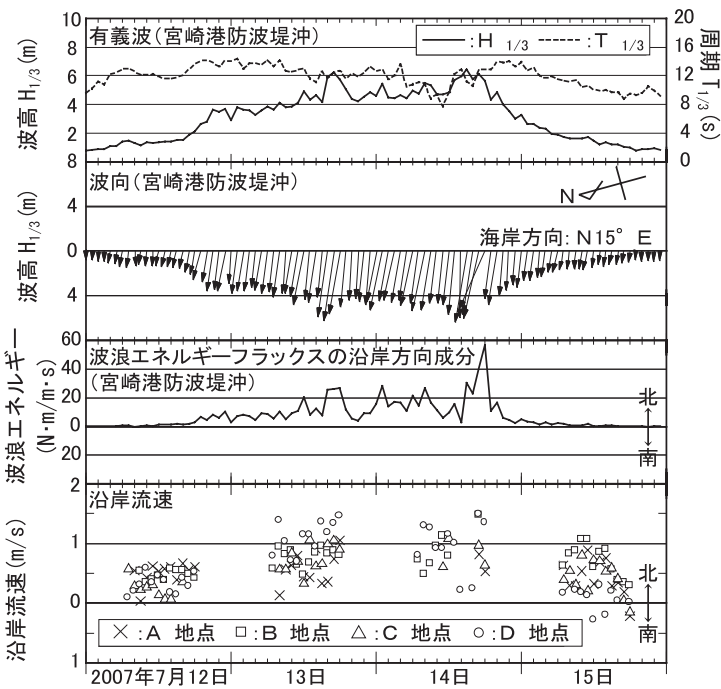

図-7 T0704号時の波浪流況

\section{5. 漂砂調査による土砂移動の実態}

2006 年 10 月, 2008 年 1 月, 2008 年 11 月の計 3 回の採取 時における各トレーサーの平均移動距離（+：北, - : 南方向）と，各トレーサー投入から採取までの期間中の 波浪エネルギーフラックスの沿岸方向成分および沿岸流 速の期間平均值の関係を図-8（a）および図-8（b）に示 す.この結果によると，トレーサーの移動方向と波浪エ ネルギーフラックスの沿岸方向成分および沿岸流速の期 間平均值の方向の関係は，黄色トレーサーが北向きに移 動した期間を除き一致しており，藤原ら（2007）の結果 と同様であった。しかしながら，黄色トレーサーが北向 きに移動した期間中は，波・流れとも黄色トレーサーの 移動方向とは逆の南向きとなり，両者は必ずしも一致し ないという結果となった。

そこで，宮崎海岸では，宮崎港における波浪とカメラ 観測による沿岸流速 $V$ が同時期に観測されていることか ら, それらから沿岸漂砂量を算出し, トレーサーとの移 動方向の関係を調べた。沿岸漂砂量は, Krausら（1982） の式（1）により算出を試みた.

$$
Q=0.024 H_{B}^{2} V
$$

ここに, $Q$ : 沿岸漂砂量 $\left(\mathrm{m}^{3} / \mathrm{s}\right), H_{B}$ : 砕波波高 $(\mathrm{m})$, $V$ : 沿岸流速 $(\mathrm{m} / \mathrm{s})$ である。なお，Vはカメラ観測によ る沿岸流速を用いており， $H_{B}$ はSunamura（1983）の式 （2）により算定した.

$$
\frac{H_{B}}{H_{O}}=(\tan \beta)^{0.2}\left(\frac{H_{O}}{L_{O}}\right)^{-0.25}
$$

ここに, $H_{B}$ : 砕波波高 $(\mathrm{m}), H_{O}$ : 沖波波高 $(\mathrm{m})$, $\tan \beta$ : 海底勾配（宮崎海岸の砕波帯内の平均的な海底勾
配 $1 / 50) ， L_{O}$ : 沖波波長 $\left(=1.56 T^{2}\right)$ である。なお， $H_{O}$ および $T$ は，ここでは宮崎港防波堤沖で観測された有義 波を用いた。

トレーサーの平均移動距離と沿岸漂砂量の関係を図-8 （c）に示す．沿岸漂砂量は各期間中の累計值である。こ の結果によると，黄色トレーサーが北向きに移動した期 間も含めて, トレーサーの移動方向と沿岸漂砂量（累計 值）の方向がいずれも一致する結果が得られた．黄色卜 レーサーが北向きに移動した期間の沿岸漂砂量の累計值 が北向きとなったことは，図-7に示すように高波浪時の 北向き沿岸流速が発生した結果, 北向き沿岸漂砂量が増

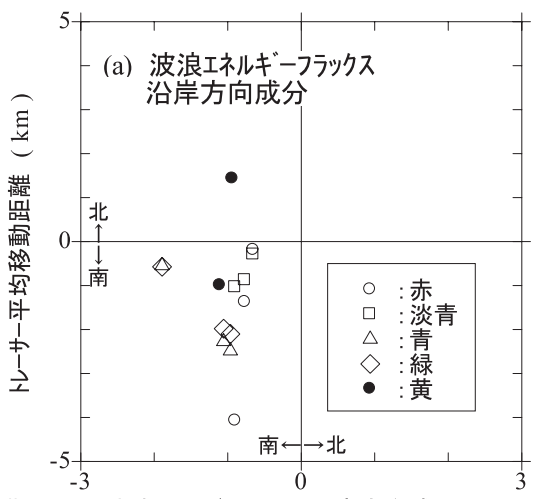

期間平均波浪エネルギーフラックス沿岸方向成分 $(\mathrm{N} \cdot \mathrm{m} / \mathrm{m} \cdot \mathrm{s})$
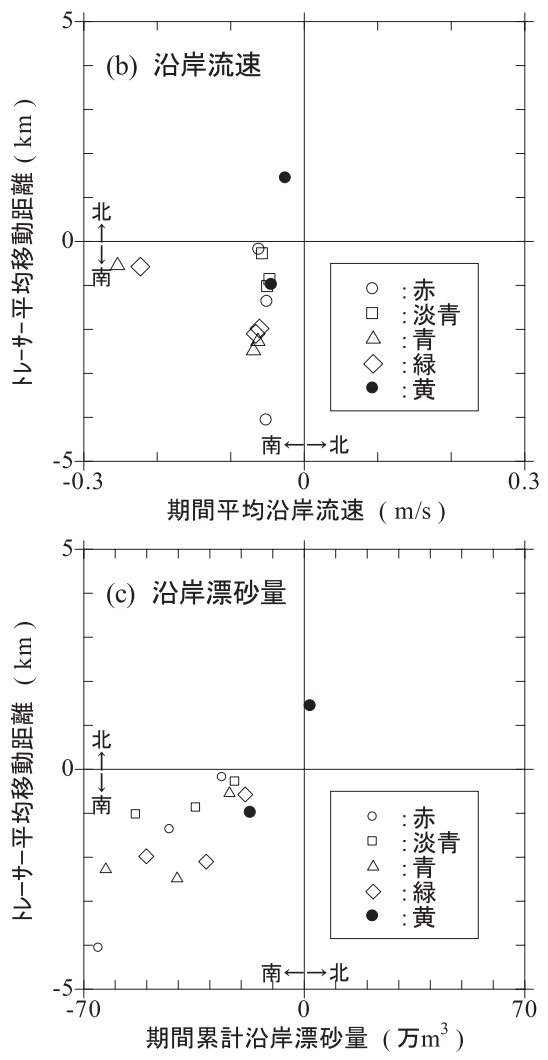

図-8 トレーサーの移動方向と外力の関係 
大したものと考えられる.ささらにこの図から累計した 沿岸漂砂量とトレーサーの平均移動距離との相関も高 く，波・流れ両方の作用により底質（土砂）の移動しや すさが決まることがわかる。

カメラ観測期間中の沿岸漂砂量の変化を図-9に示す. この結果によると, 沿岸漂砂の卓越方向は年間を通して 総じて南向きであることが確認された。また，沿岸漂砂 量としては，A， B，C地点と北から南に向けて徐々に強 まるが，D地点では弱まる傾向が見られる.

以上の漂砂調查結果から，トレーサー移動方向と沿岸 漂砂量の方向が一致し，2006年1月～2008年12月までの 3 年間の年間を通した漂砂移動は, 南向きが卓越してい たことが推定された。また，沿岸流押よび推定した沿岸 漂砂量は，北は一ツ瀬川河口，南は一ツ葉有料PAの区 間において，方向性は南方向であるものの，宮崎港に近 いD地点では弱まる傾向が見られた。

\section{6. 結論}

2006 年 1 月以降に投入したトレーサーを 3 年間に渡り 追跡調査した結果，2007年 7 月の台風時期に投入した卜 レーサーは，台風を経験した 2008 年 1 月採取時には投入 地点より北側で検出された。また，2008年11月の調查結 果によると，投入位置から南側に多く検出された。

漂砂の外力である波と流れについて解析した結果，調 查期間中の波浪の波向は海岸線に対して北寄りからの入 射が卓越しており, 南向きの波浪エネルギーフラックス が卓越していた。

カメラ画像から求めた月平均の沿岸流解析結果による と, 台風時期に北方向の流れも発生するものの, 年間を 通して概ね南方向に流れていることがわかった.

さらに，波と流れの観測值を用いて，Krausら（1982） の式により沿岸漂砂量を試算した結果, トレーサーの移 動方向と沿岸漂砂量 (累計值) の方向, さらにはトレー サーの平均移動距離と沿岸漂砂量の累計値との相関が高 いことが示された。

以上の漂砂調査結果から，北は一ツ瀬川河口，南は一 ツ葉有料PAの区間における 2006年 1月～2008年 12月ま での3年間の年間を通した漂砂移動は，南向きが卓越して

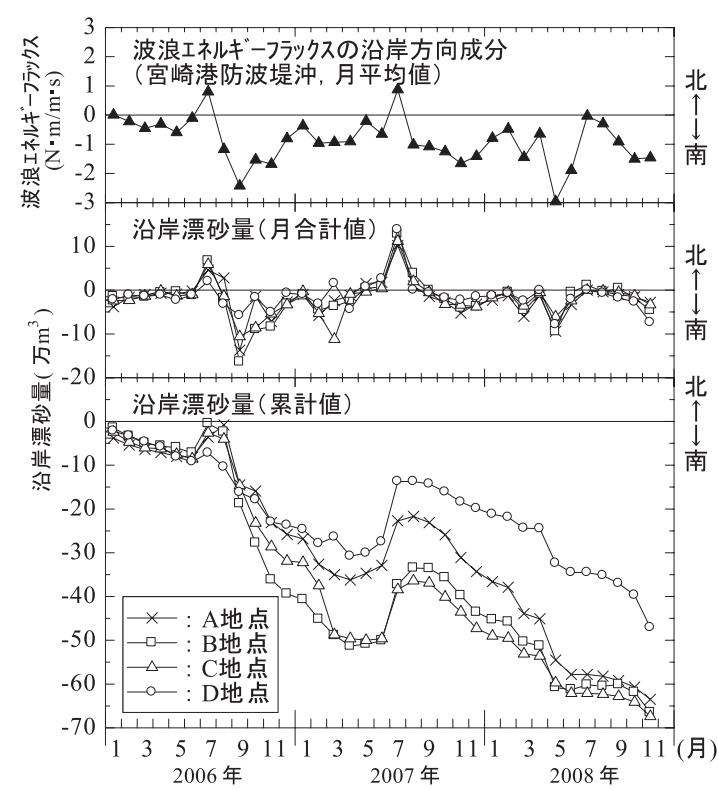

図-9 沿岸漂砂量の変化

いたことが推定された。また，沿岸流および推定した沿 岸漂砂量は，北は一ツ瀬川河口，南は一ツ葉有料PAの区 間において, 方向性は南方向であるものの, 宮崎港に近 いD地点（一ツ葉有料PA）では弱まる傾向が見られた。

謝辞：本研究で使用した宮崎港防波堤沖の波浪デー夕は 宮崎県宮崎土木事務所より提供いただいた。ここに記し て謝意を表します。

\section{参 考 文 献}

藤原 要 $\cdot$ 的場孝文・熊谷隆則 $\cdot$ 藤田裕士 ・堀口敬洋 $\cdot$ 佐々 木崇雄・高木利光（2007）：カメラ観測システムを用い た宮崎海岸の土砂移動機構調查，第54回海工論文集，pp. 671-675.

Kraus, N.C., M. Isobe, H. Igarashi, T. Sasaki and K. Horikawa (1982):Field experiments on longshore sand transport in the nearshore zone, Proc. 18th Coastal Eng. Conf., ASCE, pp.969988.

Sunamura, T.(1983):Determination of breaker height and depth in the field, Ann. Rep., Inst. Geosci., Univ. Tsukuba, No.8, pp.5354. 